\title{
Respon Viabilitas Benih Kacang Tunggak Nagara (Vigna unguiculata ssp cylindrica) Akibat Pemberian Konsentrasi Ekstrak Akar Eceng Gondok (Eichhornia crassipes)
}

\section{(Viability Responses of Nagara Cowpea (Vigna unguiculata ssp cylindrica) Due to The Concentrations of Water Hyacinth (Eichhornia crassipes)) Root Extract}

\author{
Raihani Wahdah' ${ }^{1)}$, Hikma Ellya ${ }^{2)}$, \& Hasni Hairina ${ }^{3}$ \\ ${ }^{1)}$ Program Studi Agronomi, Fakultas Pertanian, Universitas Lambung Mangkurat Banjarbaru \\ ${ }^{1)}$ raihani.wahdah@ulm.ac.id \\ ${ }^{2}$ Program Studi Agroekoteknologi, Fakultas Pertanian, Universitas Lambung Mangkurat Banjarbaru \\ ${ }^{3}$ Program Studi Agronomi, Fakultas Pertanian Universitas Lambung Mangkurat Banjarbaru
}

\begin{abstract}
ABSTRAK
Akar eceng gondok mengandung giberilin yang diharapkan dapat memperbaiki performa viabilitas benih kacang tunggak nagara. Tujuan penelitian adalah untuk mengkaji pengaruh ekstrak akar eceng gondok terhadap performa viabilitas benih kacang tunggak nagara. Penelitian dilaksanakan pada April - Oktober 2020 di Laboratorium Fisiologi Tumbuhan Fakultas Pertanian Universitas Lambung Mangkurat Banjarbaru. Penelitian ini ditata dalam Rancangan Acak Lengkap faktor tunggal, yaitu konsentrasi ekstrak akar eceng gondok (kontrol, 0 \%, $7.5 \%, 15.0 \%, 22.5 \%$, dan $30.0 \%$ ). Pengamatan dilakukan terhadap daya berkecambah benih, viabilitas potensial, persentase kecambah normal pada pengamatan pertama, kecepatan tumbuh benih, keserempakan tumbuh benih, panjang akar dan panjang plumula kecambah normal kuat, serta berat kering kecambah normal. Perlakuan yang berpengaruh nyata, maka dilakukan uji DMRT dilakukan pada peubah yang dipengaruhi perlakuan berdasarkan analisis ragam. Perlakuan priming $0.0 \%$ lebih baik daripada perlakuan tanpa priming, kecuali panjang akar. Perlakuan priming $7.5 \%$ paling efisien untuk daya berkecambah benih, potensi perkecambahan benih, dan keserempakan tumbuh benih. Perlakuan priming $22.5 \%$ paling efisien untuk persentase perkecambahan hari ke-5, kecepatan tumbuh benih, panjang plumula, dan berat kering kecambah normal.
\end{abstract}

Kata kunci: Kacang tunggak nagara, konsentrasi, ekstrak, akar eceng gondok, viability.

\begin{abstract}
Water hyacinth root contains gibberellin which was expected to improve the viability performance of nagara cowpea. This research aimed to study the effect of water hyacinth root extract on the viability of nagara cowpea. The research was carried out in April - October 2020 at the Plant Physiology Laboratory, Faculty of Agriculture, Lambung Mangkurat University, Banjarbaru. This research was arranged in a single factor completely randomized design, namely the concentration of water hyacinth root extract (control, $0 \%, 7.5 \%, 15.0 \%, 22.5 \%$, and 30.0\%). Observations were made on seed germination, viability potential, percentage of normal seedling at first observation, growth speed, uniformity of growth, root and plumule length of strong normal seedling, and dry weight of normal seedling. DMRT test carried out on variables affected by treatment based on analysis of variance. The $0.0 \%$ priming was better on all variables than the without priming, except for the root length. The $7.5 \%$ priming treatment was the most efficient for seed germination, potential germination of seeds, and growth uniformity of seeds. The $22.5 \%$ priming treatment was the most efficient for the germination percentage in first observation, seed growth speed, plumule length, and dry weight of normal seedling.
\end{abstract}

Keywords: Nagara cowpea, concentration, extract, water hyacinth root, viability.

Article History Submitted: October 25, 2020 Approved with minor revision: December 4, 2020 Accepted: December 4, 2020 Published: December 29, 2020

\section{PENDAHULUAN}

Kacang tunggak nagara umumnya ditanam di lahan rawa lebak Nagara (Kecamatan Daha Utara dan Daha Selatan), Kabupaten Hulu Sungai Selatan, 
Kalimantan Selatan. Kacang tunggak nagara mengandung protein yang cukup tinggi, walaupun lebih rendah daripada kedelai. Menurut (Noor, G. M., Moehansyah, Jurindar, A.M., Supiyatna, Balantek, R., 1993), kandungan protein kacang tunggak nagara adalah $22.00 \%-$ $27.00 \%$, kacang tunggak $22,50 \%$, kacang hijau 21,82 \%, dan kedelai 38,19\%.

Budidaya kacang tunggak nagara di lahan rawa lebak hanya dilakukan satu kali setahun. Oleh karena itu, benih yang dipanen pada tahun $\mathrm{X}$ akan ditanam pada tahun $\mathrm{X}+1$ (sekitar 8 bulan kemudian), sehingga dapat menyebabkan penurunan mutu benih (viabilitas benih), pertumbuhan, dan hasil tanaman. Upaya untuk memperbaiki mutu benih antara lain dapat dilakukan dengan invigorasi benih, yaitu upaya untuk memaksimalkan potensi viabilitas benih dengan cara priming benih. Priming sangat membantu dalam meningkatkan persentase kemunculan bibit kacang tunggak (Eskandari \& Kazemi, 2011). Pada percobaan lapang, priming benih kacang tanah dan kacang tunggak meningkatkan hasil masing-masing $18.2 \%$ dan 25.5\% (Ousman \& Aune, 2011).

Priming benih kacang tunggak nagara dengan air (hydropriming) selama 8 jam meningkatkan daya berkecambah benih dari $61.56 \%$ menjadi $83.33 \%$, namun perlakuan osmopriming dengan Poli Etilen Glikol (PEG) tidak memberikan pengaruh yang lebih baik terhadap peubah viabilitas benih (Wahdah \& Susanti, 2020). Namun demikian (Wahdah \& Susanti, 2019) melaporkan bahwa perlakuan $2.5 \%$ PEG cenderung lebih baik daripada $0 \%$ PEG.

\section{Eceng gondok (Eichhornia} crassipes), merupakan sumberdaya lokal yang banyak terdapat di lahan rawa lebak. Kalimantan Selatan. Eceng gondok merupakan tanaman yang hidup mengapung di air (Artati et. al., 2009; (Putera, 2012), yaitu pada perairan yang dalam dan tenang (Putera, 2012). Eceng gondok merupakan tumbuhan air tawar yang dikenal sebagai gulma yang dapat tumbuh dengan cepat (Artati et. al., 2009;
Fachry et. al., 2010) hingga $3 \%$ per hari (Fachry et. al., 2010) dan menimbulkan berbagai masalah (Artati et. al., 2009); Fachry et. al., 2010). Namun demikian, eceng gondok juga dapat dimanfaatkan, antara lain pada bidang pertanian.

Ekstrak daun eceng gondok dapat digunakan sebagai pupuk organik untuk perkecambahan benih dan pertumbuhan bibit (Poudel et al., 2018). Akar eceng gondok mengandung hormon tumbuh, yaitu giberilin (Musbakri, 1999). (Widodo et. al., 2016) menyimpulkan bahwa filtrat eceng gondok mempunyai efek seperti ZPT alami pada media $\mathrm{AB}$ MIX pada kangkung (Ipomoea reptans. P) yang ditanam dengan sistem hidroponik.

Penambahan 20 ppm hormon tumbuh, efektif menginduksi laju perkecambahan, total berat kering kecambah, dan keserempakan tumbuh benih. Priming selama 6 jam lebih baik daripada 12 jam (Saeedipour, 2013).

Dengan demikian, priming benih kacang tunggak nagara dengan ekstrak akar eceng gondok pada konsentrasi yang tepat diharapkan dapat meningkatkan performa viabilitas benih kacang tunggak nagara. Berdasarkan latar belakang di atas, maka perlu dilakukan kajian pemberian beberapa tingkat konsentrasi ekstrak akar eceng gondok terhadap performa viabilitas benih kacang tunggak nagara sebagai upaya pendukung pengembangan pertanian tanaman pangan di lahan basah.

\section{KAJIAN LITERATUR DAN HIPOTESIS}

\section{Priming Benih}

Periode perkecambahan benih merupakan periode yang sangat rentan Berbagai metode invigorasi telah dikembangkan dan pengaruhnya spesifik pada setiap jenis benih (Erinnovita et. al., 2008). Invigorasi benih adalah perlakuan yang diberikan untuk meningkatkan viabilitas benih (daya berkecambah dan vigor) yang ditunjukkan oleh perbaikan performansi benih, baik secara fisiologis maupun biokemis, dengan berbagai 
perlakuan benih pascapanen atau pratanam, antara lain hydropriming, osmopriming, biopriming, dan organic priming (Ilyas, 2001).

Priming sangat membantu dalam meningkatkan persentase kemunculan bibit kacang tunggak (Eskandari \& Kazemi, 2011). Pada percobaan lapang, priming benih kacang tanah dan kacang tunggak meningkatkan hasil masing-masing $18.2 \%$ dan 25.5\% (Ousman \& Aune, 2011)

Hydropriming pada benih kacang tunggak menunjukkan daya perkecambahan dan pertumbuhan kecambah menjadi lebih baik (Wahdah \& Susanti, 2019). Penambahan $20 \mathrm{ppm}$ hormon tumbuh, efektif menginduksi laju perkecambahan, total berat kering kecambah, dan keserempakan tumbuh benih. Priming selama 6 jam lebih baik daripada 12 jam (Saeedipour, 2013). Hydropriming pada kacang tunggak dapat meningkatkan performa mutu benih (Singh et. al., 2014).

Organic priming dengan ekstrak daun kelor $2 \%$ pada benih wijen memberikan pengaruh yang lebih baik terhadap semua peubah viabilitas, kecuali waktu awal berkecambah (Shabbir et. al., 2014). Ekstrak bunga Marigold (Tagetes patula dan Tagetes erecta) dapat digunakan sebagai organic priming untuk meningkatkan kualitas benih (daya berkecambah, bobot segar kecambah, waktu munculnya kecambah benih) lada, jika dipanen pada saat yang tepat (Mavi, 2016).

\section{Eceng Gondok dan Pengaruhnya pada Tanaman}

Akar eceng gondok mengandung hormon giberelin (Musbakri, 1999). Giberilin yang dikombinasikan dengan pupuk nitrogen berpengaruh terhadap pertumbuhan dan hasil padi Inpari 10. Hasil penelitian (Sittadewi, 2007) menunjukkan bahwa pemberian $0.5 \mathrm{~kg}$ pupuk organik eceng gondok pada sawi hibrida menghasilkan berat segar tanaman sebesar 45 g pada umur 40 hari dan lebih baik dibandingkan dengan pertumbuhan pada pemberian $0,25 \mathrm{~kg}$ pupuk organik eceng gondok dan kontrol. Giberilin yang dikombinasikan dengan pupuk nitrogen berpengaruh terhadap pertumbuhan dan hasil padi Inpari 10. Takaran pupuk nitrogen $90 \mathrm{~kg} \mathrm{~N}^{-1}$ yang dikombinasikan dengan konsentrasi giberelin $10 \mathrm{ppm}$ menunjukkan pengaruh jumlah anakan per rumpun, jumlah anakan produktif per rumpun, panjang akar, volume akar, jumlah gabah per malai, jumlah gabah isi per malai, dan bobot gabah per plot terbaik (Toharudin \& Sutomo, 2013).

Eceng gondok mengandung alkaloids, flavonoids, phenols, sterols, terpenoids, anthoquinones dan protein (Lalitha \& Jayanthi, 2012). Ekstrak daun eceng gondok dapat digunakan sebagai pupuk organik untuk perkecambahan benih dan pertumbuhan bibit (Poudel et. al., 2018; Vidya \& Girish, 2014). Selanjutnya dilaporkan oleh Poudel et. al., (2018), bahwa awal perkecambahan benih $P$. roxburghii terbaik adalah pada perlakuan konsentrasi ekstrak eceng gondok dengan rasio 75:25 dan rasio 50:50, tetapi jumlah benih berkecambah paling banyak adalah pada konsentrasi 25:75.

Ekstrak daun eceng gondok dapat digunakan sebagai pupuk organik untuk perkecambahan benih dan pertumbuhan bibit (Poudel et. al., 2018); Vidya \& Girish, 2014). Selanjutnya dilaporkan oleh Poudel et al., (2018), bahwa awal perkecambahan benih $P$. roxburghii terbaik adalah pada perlakuan konsentrasi ekstrak eceng gondok dengan rasio 75:25 dan rasio 50:50, tetapi jumlah benih berkecambah paling banyak adalah pada konsentrasi 25:75. Menurut Vidya \& Girish, (2014), pemberian pupuk organik eceng gondok pada tanaman gandum menunjukkan nilai yang lebih baik pada peubah jumlah benih yang berkecambah,

\section{Hipotesis}

Berdasarkan kajian literatur di atas, maka hipotesis penelitian ini adalah pada konsentrasi tertentu ekstrak akar eceng gondok lebih baik daripada control (tanpa priming) dan priming dengan konsentrasi $0.0 \%$ (hidropriming). 


\section{METODE PENELITIAN}

Penelitian dilaksanakan pada April - Oktober 2020 di Laboratorium Fakultas Pertanian Universitas Lambung Mangkurat Banjarbaru. Bahan yang digunakan adalah benih kacang nagara, ekstrak eceng gondok, kertas uji, akuades, plastik, karet gelang, sedangkan alat yang digunakan adalah alat pengecambah benih, alat pengepress kertas, baskom perendam kertas, toples perendam benih, oven, timbangan, penggaris, dan alat-alat untuk pengujian viabilitas benih.

Penelitian ini merupakan penelitian eksperimen yang ditata dalam Rancangan Acak Lengkap faktor tunggal, yaitu konsentrasi ekstrak akar eceng gondok (kontrok, $0 \%, 7.5 \%, 15.0 \%, 22.5 \%$, dan $30.0 \%)$. Perlakuan control adalah perlakuan tanpa priming, sedangkan perlakuan lainnya adalah perlakuan priming selama 9 jam pada masing-masing konsentrasi. Pengamatan dilakukan terhadap daya berkecambah benih, viabilitas potensial, dan vigor kekuatan tumbuh, yaitu persentase kecambah normal pengamatan pertama (hari ke-5), kecepatan tumbuh, keserempakan tumbuh, panjang akar kecambah normal kuat, panjang plumula kecambah normal kuat, serta berat kering kecambah normal.

Data yang diperoleh diuji kehomogenan ragamnya dengan $\mathrm{Uji}$ Bartlett, selanjutnya dilakukan Analisis Varians (Anava) mengikuti model linear aditif, yaitu :

$$
\begin{aligned}
& \mathrm{Y}_{\mathrm{ij}}=\mu+\alpha_{\mathrm{i}}+{ }_{\mathrm{j}}+€_{\mathrm{ij}} \\
& \mathrm{Y}_{\mathrm{ij}}= \text { penampilan yang dipengaruhi } \\
& \text { oleh konsentrasi ekstrak akar } \\
& \text { eceng gondok ke-i, ulangan } \\
& \text { ke- } \mathrm{j} \\
& \mu= \text { nilai tengah perlakuan } \\
& \alpha_{\mathrm{i}}= \text { pengaruh konsentrasi ekstrak } \\
& \text { akar eceng gondok ke- } \mathrm{i} \\
& €_{\mathrm{ij}}= \text { pengaruh galat acak dari } \\
& \text { satuan percobaan ke-j yang } \\
& \text { mendapat perlakuan ke-i. }
\end{aligned}
$$

Pengujian dengan DMRT (Duncan Multiple Range Test) pada taraf nyata $5 \%$.

$$
\mathrm{R}_{\mathrm{p}}=\mathrm{q}_{\alpha / 2} \sqrt{ }(2 \mathrm{KTG} / \mathrm{r})
$$

$$
\begin{aligned}
& \mathrm{R}_{\mathrm{p}}=\text { wilayah nyata terkecil } \\
& \mathrm{q}_{\alpha}=\text { nilai tabel DMRT pada } \mathrm{db}
\end{aligned}
$$

\section{HASIL DAN PEMBAHASAN}

\section{Hasil}

\section{Daya Berkecambah dan Potensi Perke- cambahan Benih}

Semua peubah menunjukkan ragam homogen. Uji analisis varians menunjukkan bahwa perlakuan berpengaruh nyata terhadap daya berkecambah benih dan potensi perkecambahan. Hasil uji DMRT pengaruh perlakuan dapat dilihat pada Gambar 1.

Berdasarkan Gambar 1a dapat dilihat bahwa perlakuan hydropriming (0.0 $\%)$ lebih baik daripada perlakuan kontrol (tanpa priming) pada peubah daya berkecambah benih, masing-masing dengan nilai DB $40.67 \%$ dan $76 \%$. Pada peubah potensi perkecambahan benih tidak terdapat perbedaan yang nyata antara control dengan perlakuan $0.0 \%$, yaitu $71.33 \%$ dan $75.33 \%$ (Gambar 1b). Selanjutnya dapat dilihat bahwa perlakuan priming dengan ekstrak eceng gondok 7.5$30.0 \%$ lebih baik daripada perlakuan control dan hidropriming, baik pada peubah daya berkecambah benih $(92.00$ $94.87 \%$ ) maupun potensi perkecambahan benih (90.00-94.00\%). Perlakuan $7.5 \%$ ekstrak akar eceng gondok merupakan perlakuan yang paling efisien untuk kedua peubah tersebut, karena lebih baik daripada control dan perlakuan $0.0 \%$ dan tidak berbeda nyata dengan perlakuan 15.0, 22.5, dan $30.0 \%$ ekstrak akar eceng gondok (Gambar 1a dan 1b). 


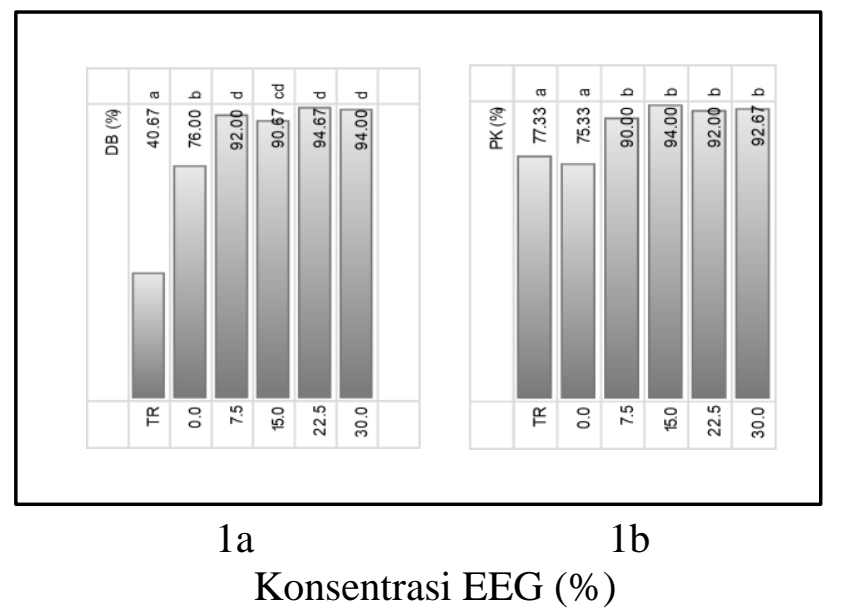

Gambar 1. Pengaruh ekstrak eceng gondok terhadap daya berkecambah (DB) dan potensi perkecambahan benih (PK) berdasarkan uji DMRT.

\section{Vigor Benih}

Uji kehomogenan ragam menunjukkan bahwa semua peubah vigor menunjukkan ragam yang homogen. Uji analisis varians menunjukkan bahwa perlakuan berpengaruh nyata terhadap peubah vigor kecuali panjang akar. Hasil uji DMRT pengaruh perlakuan dapat dilihat pada Gambar 2.

Berdasarkan pada Gambar 2a-2e, dapat dilihat bahwa perlakuan hydropriming lebih baik daripada perlakuan kontrol terhadap daya berkecambah pengamatan pertama (20.70 dan $8.00 \%$ ), kekuatan tumbuh (25.33 dan $2.00 \%$ etmal), keserempakan tumbuh (2.00 dan $25.33 \%)$, panjang plumula $(7.97-10.4 \mathrm{~cm})$, dan berat kering kecambah normal $(0.46-$ 1.28 g). Perlakuan $22.5 \%$ ekstrak eceng gondok menghasilkan persentase kecambah normal pada pengamatan pertama paling tinggi dibandingkan dengan perlakuan lainnya, yaitu 38.00 \% (Gambar 2a). Demikian juga terhadap peubah kecepatan tumbuh benih (20.93\% etmal), walaupun tidak berbeda nyata dengan perlakuan $7.5 \%$. Kecepatan tumbuh benih pada perlakuan $7.5 \%$ tidak berbeda nyata dengan $15.0 \%$ ekstrak akar eceng gondok (Gambar 2b).

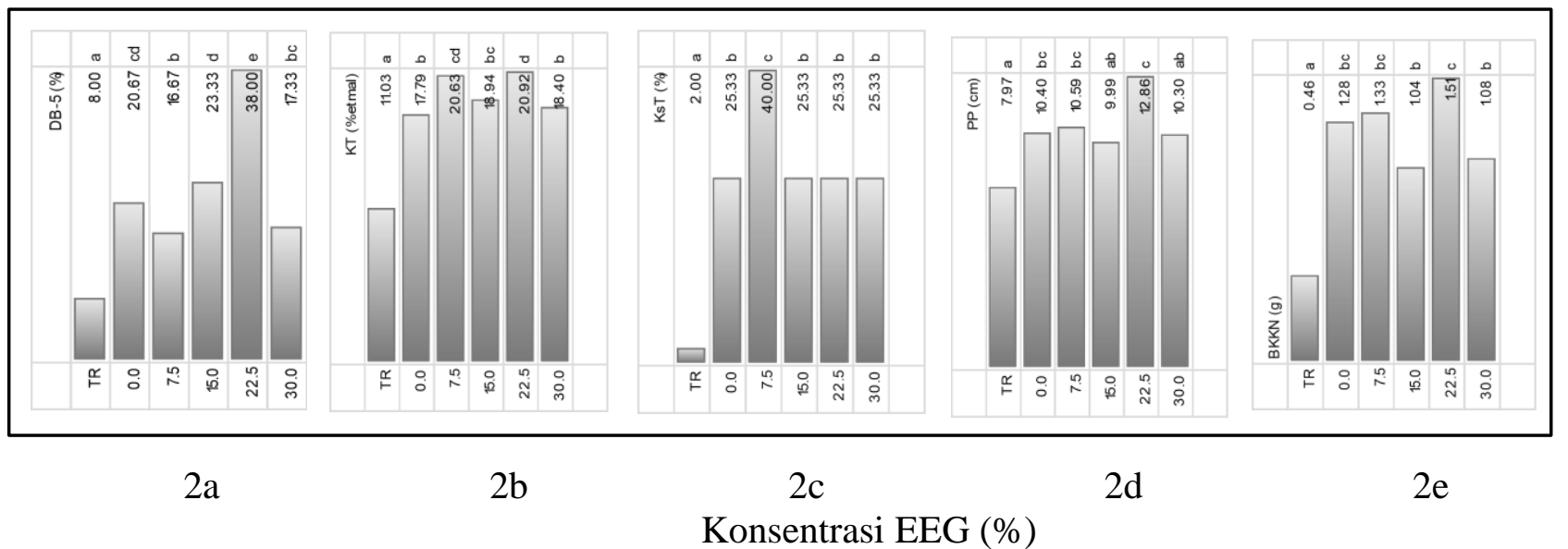

Gambar 2. Pengaruh ekstrak eceng gondok terhadap keserempakan tumbuh (KsT), kecepatan tumbuh (KT), panjang plumula (PP), dan berat kering kecambah normal (BKKN) berdasarkan uji DMRT. 
Pada peubah keserempakan tumbuh benih, perlakuan $7.5 \%$ menunjukkan nilai keserempakan tumbuh terbaik (41.00\%) dibandingkan dengan konsentrasi lainnya (Gambar 2c).

Pada Gambar 2d (peubah panjang plumula), dapat dilihat bahwa, perlakuan $22.5 \%$ adalah yang paling efisien (12.86 $\mathrm{cm})$, karena walaupun tidak berbeda nyata dengan perlakuan $0.0 \%(10.40 \mathrm{~cm})$ dan $7.5 \%(10.90 \mathrm{~cm})$, tetapi kedua konsentrasi tersebut tidak berbeda nyata dengan perlakuan $15 \%$ dan $30.0 \%$, sedangkan perlakuan $22.5 \%$ berbeda nyata dengan perlakuan $15 \%$ dan $30 \%$.

Perlakuan yang paling efisisen untuk berat kering kecambah normal juga $22.5 \%$ yaitu $1.51 \mathrm{~g}$ (Gambar 2e). karena walaupun tidak berbeda nyata dengan perlakuan $0.0 \%(1.26 \mathrm{~g})$ dan $7.5 \%$ (1.33 g), tetapi kedua konsentrasi tersebut tidak berbeda nyata dengan perlakuan $15 \%$ dan $30.0 \%$, sedangkan perlakuan $22.5 \%$ berbeda nyata dengan perlakuan $15 \%$ dan $30 \%$.

\section{Pembahasan}

Priming benih adalah teknik hidrasi terkontrol yang memicu proses metabolisme normal selama fase awal perkecambahan sebelum penonjolan radikula (Hussain et. al., 2015). Menurut (Khan, 1992), invigorasi adalah perlakuan benih yang menyeimbangkan potensial air benih untuk merangsang kegiatan metabolisme di dalam benih sehingga benih siap berkecambah tetapi struktur penting embrio, yaitu radikula belum muncul. Itulah sebabnya priming dengan air (hydropriming) mampu meningkatkan viabilitas benih seperti yang diperoleh pada semua peubah dalam penelitian ini, kecuali peubah panjang akar dan keserempakan tumbuh benih

Priming benih dengan bahan organik, menyebabkan benih tidak saja menyerap air, tetapi juga menyerap bahan bermanfaat dalam proses perkecambahan benih. Perbaikan potensi perkecambahan dan daya berkecambah benih seperti yang ditunjukkan dalam penelitian ini, diduga disebabkan oleh bekerjanya hormon tumbuh giberilen yang terdapat pada ekstrak akar eceng gondok, menggantikan giberilin yang seharusnya dihasilkan oleh benih jika benih tersebut mempunyai viabilitas yang tinggi. Hal ini terlihat pada perlakuan konsentrasi ekstrak eceng yang menunjukkan lebih baik daripada hanya hydropriming (Gambar 1 dan 2).

Giberelin (GA3) 1500 mg.l $^{-1}$ dan waktu perendaman selama 9 jam dapat meningkatkan daya kecambah benih cemara laut (Ayuningtyas et. al., 2017). (Muchtaromah et. al., 2006), melaporkan bahwa enceng gondok mempunyai kandungan protein yang cukup tinggi, yaitu 12-18 \% serta mempunyai kandungan asam amino yang cukup lengkap yang dapat dimanfaatkan sebagai pengganti hormon giberelin. (Musbakri, 1999) juga menyatakan bahwa akar eceng gondok (Eichhornia crassipes) mengandung hormon giberelin.

Ummah dan (Ummah \& Rahayu, 2019), melaporkan bahwa konsentrasi optimal ekstrak akar eceng gondok (Eichhornia crassipes) sebagai priming organic yang menghasilkan daya berkecambah $80.55 \%$ pada benih lengkeng adalah $0.05 \% \quad(500 \quad \mathrm{ppm})$. Priming organik dengan konsentrasi urine sapi 2\% dapat direkomendasikan untuk meningkatkan vigor benih cluster bean pada ekosistem tadah hujan (Ambika \& Balakrishnan, 2015).

Proses imbibisi air diikuti dengan peningkatan aktivitas respirasi dan enzim untuk perombakan cadangan makanan yang diikuti dengan asimilasi di daerah meristematik untuk menghasilkan energi baru, pembentukan komponen dan pertumbuhan sel baru. (Sutopo, 2004). (Mandal \& Chakraborti, 2017), melaporkan meningkatnya karakter perkecambahan dan pembibitan benih kacang tunggak yang diberi urine dan 
larutan kotoran sapi. Menurut mereka perbaikan tersebut terkait dengan enzim alpha amylase. Proses perkecambahan lebih lajut dijelaskan oleh (Kamil, 1986), yaitu setelah benih menyerap air, terjadi pengaktivan enzim-enzim yang kemudian masuk ke dalam endosperm dan mencerna zat makanan. Enzim amilase merombak pati menjadi gula seperti glukosa, fruktosa, atau sukrosa. Enzim lipase merombak lemak menjadi gliserin dan asam lemak, sedangkan enzim protease merombak protein menjadi asam amino.

Sejalan dengan hasil penelitian ini, (Ansari \& Zadeh, 2012), melaporkan bahwa hydropriming (perendaman dengan air) dapat meningkatkan daya berkecambah benih Secale montanum. (Eskandari \& Kazemi, (2011) melaporkan bahwa secara keseluruhan perlakuan hydropriming secara komparatif lebih baik berdasarkan uji laboratorium. Disimpulkan oleh mereka bahwa perlakuan hydropriming dapat meningkatkan persentase munculnya kecambah dan laju perkecambahan kacang tunggak. (Wahdah \& Susanti, 2019) melaporkan bahwa perendaman benih dengan air, meningkatkan daya berkecambah benih, yaitu dari $61.56 \%$ menjadi $83.33 \%$, kecepatan tumbuh benih dari $29.36 \%$ etmal menjadi $10.64 \%$ etmal, indeks vigor dari $22.22 \%$ menjadi $40.00 \%$, keserempakan tumbuh benih dari $51.56 \%$ - $66.00 \%$, berat kering kecambah normal dari $0.33 \mathrm{~g}$ menjadi $0.49 \mathrm{~g}$, panjang akar dari $8.75 \mathrm{~cm}$ menjadi $13.52 \mathrm{~cm}$, dan panjang plumula dari $7.09 \mathrm{~cm}$ menjadi $9.93 \mathrm{~cm}$.

Priming benih dengan bahan organik, tidak saja dapat memperbaiki daya berkecambah benih, tetapi juga vigor benih semangka seperti yang dilaporkan oleh (Marliah et. al., 2010) Dilaporkan bahwa ekstrak buah semangka lebih baik daripada ekstrak pisang ambon, ekstrak jagung muda, dan ekstrak kelapa muda. Dinyatakan pula bahwa responnya tergantung kepada viabilitas awal (masa kadaluarsa). Semakin rendah viabilitas benih (semakin lama masa kadaluarsa), maka semakin rendah kemampuan ekstrak untuk memperbaiki viabilitas dan vigor benih.

Persentase benih yang berkecambah normal pada hitungan pertama (5 hari setelah tabor) adalah merupakan salah satu parameter vigor benih. Menurut (Sadjad, 1993), vigor benih adalah kemampuan benih untuk berkecambah normal pada kondisi yang suboptimum atau di atas normal pada kondisi yang optimum. (Jisha et. al., 2013) menyatakan bahwa dalam lingkungan yang tidak menguntungkan (tidak optimum). priming benih adalah teknik yang efektif, praktis dan mudah untuk meningkatkan kemunculan yang cepat dan seragam, kekuatan bibit yang tinggi, dan hasil yang lebih baik pada banyak jenis tanaman.

Aplikasi hormon giberelin eksogen yang diekstraksi dari akar Eichhornia crassipes menunjukkan viabilitas terbaik dan waktu perkecambahan terpendek. Hasil temuan menunjukkan adanya sinergisme yang positif antara giberelin eksogen dan endogen pada efek proses perkecambahan benih Annona muricata, Manilkara kauki, dan Dimocarpus longan (Ummah \& Rahayu, 2019).

Sejalan dengan hasil penenlitian ini, dilaporkan bahwa hydropriming merupakan perlakuan benih yang sangat penting untuk kecepatan tumbuh benih pada berbagai tanaman biji-bijian. Priming organic ekstrak rumput laut dengan perbandingan 1:500 menunjukkan hasil yang terbaik terhadap laju tumbuh benih merica. Efek positif juga diperoleh pada priming dengan ekstrak rumput laut perbandingan 1:1000, dan 0:1 (Sivritepe, 2008). Perendaman benih dengan ekstrak akar eceng gondok hingga konsentrasi 30 $\%$ lebih baik daripada control (tanpa perendaman benih). Menurut Abebe \& Modi, (2009), Hidropriming merupakan 
perlakuan benih yang sangat penting tidak hanya untuk kecepatan tumbuh tetapi juga keserempakan tumbuh benih pada berbagai tanaman biji-bijian

Priming benih adalah teknik yang efektif, praktis dan mudah untuk meningkatkan kemunculan yang cepat dan seragam, kekuatan bibit yang tinggi, dan hasil yang lebih baik pada banyak jenis tanaman, terutama di bawah kondisi lingkungan yang tidak menguntungkan (Jisha et. al., 2013). Hydropriming merupakan perlakuan benih yang sangat penting untuk kecepatan tumbuh dan keserempakan tumbuh benih pada berbagai tanaman biji-bijian (Abebe \& Modi, 2009).

Invigorasi benih melalui proses priming berpengaruh positif terhadap pertumbuhan awal tanaman, pertumbuhan kecambah, dan kecepatan tumbuh berkecambah pada tanaman jagung dan gandum. Keberhasilan perlakuan priming pada benih dipengaruhi oleh interaksi yang kompleks dari berbagai faktor, seperti spesies tanaman, potensial air dari bahan priming, lama waktu priming, suhu udara dan suhu media tanam serta vigor benih (Arief \& Koes, 2010; Parera \& Cantliffe, 1994).

\section{KESIMPULAN}

1. Perlakuan priming benih kacang tunggak nagara dengan ekstrak akar eceng gondok berpengaruh nyata terhadap semua peubah, kecuali panjang akar kecambah.

2. Perlakuan priming $0.0 \%$ ekstrak eceng gondok pada semua peubah yang dipengaruhi perlakuan lebih baik daripada perlakuan tanpa priming.

3. Perlakuan priming $7.5 \%$ paling efisien untuk daya berkecambah benih, potensi perkecambahan benih, dan keserempakan tumbuh benih

4. Perlakuan priming $22.5 \%$ paling efisien untuk persentase perkecambahan hari ke-5, kecepatan tumbuh benih, panjang plumula, dan berat kering kecambah normal.

\section{DAFTAR PUSTAKA}

Abebe, A. T., \& Modi, A. T. (2009). Hydro-priming in dry bean (Phaseolus vulgaris L.). Research Journal of Seed Science, 2(2), 23-31. https://doi.org/10.3923/rjss.2009.23.3 1

Ambika, S., \& Balakrishnan, K. (2015). Enhancing germination and seedling vigour in cluster bean by organic priming. Scientific Research and Essays, 10(8), 298-301.

Ansari, O., \& Zadeh, F. S. (2012). Osmo and hydro priming mediated germination improvement under cold stress conditions in mountain rye (Secale montanum). Cercetari Agronomice in Moldova, 45(3), 5362.

Arief, R., \& Koes, F. (2010). Invigorasi benih. Prosiding Pekan Serealia Nasional, 29(3).

Artati, E. K., Effendi, A., \& Haryanto, T. (2009). Pengaruh konsentrasi larutan pemasak pada proses delignifikasi eceng gondok dengan proses organosolv. Ekuilibrium, 8(1), 25-28.

Ayuningtyas, V. K., Tahir, M., \& Same, M. (2017). Pengaruh Waktu Perendaman dan Konsentrasi Giberelin (GA3) pada Pertumbuhan Benih Cemara Laut (Casuarina equisetifolia L.). Jurnal Agro Industri Perkebunan, 5(1), 29-38.

Erinnovita, E., Sari, M., \& Guntoro, D. (2008). Invigorasi benih untuk memperbaiki perkecambahan kacang panjang (Vigna unguiculata Hask. ssp. sesquipedalis) pada cekaman salinitas. Indonesian Journal of 
Agronomy, 36(3), 7892.

Eskandari, H., \& Kazemi, K. (2011). Effect of seed priming on germination properties and seedling establishment of cowpea (Vigna sinensis). Notulae Scientia Biologicae, 3(4), 113-116.

Fachry, A. R., Sari, T. I., Dipura, A. Y., \& Najamudin, J. (2010). Mencari Suhu Optimal Proses Karbonisasi Dan Pengaruh Campuran Batubara terhadap Kualitas Briket Eceng Gondok. Jurnal Teknik Kimia, 17(2).

Hussain, S., Zheng, M., Khan, F., Khaliq, A., Fahad, S., Peng, S., Huang, J., Cui, K., \& Nie, L. (2015). Benefits of rice seed priming are offset permanently by prolonged storage and the storage conditions. Scientific Reports, 5(1), 1-12.

Ilyas, S. (2001). Mutu Benih. Fakultas Pertanian Universitas Tanjungpura.

Jisha, K. C., Vijayakumari, K., \& Puthur, J. T. (2013). Seed priming for abiotic stress tolerance: an overview. Acta Physiologiae Plantarum, 35(5), 1381-1396.

Kamil, J. (1986). Dasar Teknologi Benih. Angkasaraya. Padang.

Khan, A. A. (1992). Preplant physiological seed conditioning. Horticultural Reviews, 13(1), 131-181.

Lalitha, T. P., \& Jayanthi, P. (2012). Preliminary studies on phytochemicals and antimicrobial activity of solvent extracts of Eichhornia crassipes (Mart.) Solms. Asian J Plant Sci Res, 2(2), 115-122.

Mandal, J., \& Chakraborti, P. (2017). Improved nature of cowpea seedling and germination accompanying alphaamylase in seed treatment of cowexcreta. Research on Crops, 18(3),
$554-558$.

Marliah, A., Nasution, M., \& Azmi, S. (2010). Pengaruh masa kadaluarsa dan penggunaan berbagai ekstrak bahan organik terhadap viabilitas dan vigor benih semangka (Citrullus vulgaris Schard.). Jurnal Agrista, 14(2), 44-50.

Mavi, K. (2016). The effect of organic priming with Marigold herbal tea on seeds quality in Aji pepper (Capsicum baccatum var. pendulum Willd.). Mustafa Kemal Üniversitesi Ziraat Fakültesi Dergisi, 21(1).

Muchtaromah, B., Susilowati, R., \& Kusumastuti, A. (2006).

Pemanfaatan Tepung Hasil

Fermentasi Eceng Gondok (Eichornia Crassipes) Sebagai Campuran Pakan Ikan Untuk Meningkatan Berat Badan dan Daya Cerna Protein Ikan Nila Merah (Oreochromis sp)"(Refleksi surat Ali Imran 190-191). ElQUDWAH.

Musbakri. (1999). Ekstraksi dan Identifikasi Geberelin dari Ekar Eceng Gondok (Eichhornia Crassipes (Mart. Solms). Institut Pertanian Bogor.

Noor, G. M., Moehansyah, Jurindar, A.M., Supiyatna, Balantek, R., \& H. (1993). Prospek pengembangan kacang nagara ( Vigna sp.) di Kalimantan Selatan. Kalimantan Agrikultura, 1(2), 21-24.

Ousman, A., \& Aune, J. B. (2011). Effect of seed priming and micro-dosing of fertilizer on groundnut, sesame and cowpea in Western Sudan. Experimental Agriculture, 47(3), 431-443.

Parera, C. A., \& Cantliffe, D. J. (1994). Presowing seed priming. 
Horticultural Reviews, 16(16), 109141.

Poudel, D., Mandal, R. A., \& Ghimire, R. P. (2018). Effects of leaves extract of Eichhornia crassipes on seed germination and seedling growth of Pinus roxburghii and Bauhinia purpurea. Journal of Aquatic Science and Marine Biology, 1(2), 13-19.

Putera, R. D. H. (2012). Ekstraksi serat selulosa dari tanaman eceng gondok (Eichornia crassipes) dengan variasi pelarut. Skripsi Fakultas Teknik Universitas Indonesia.

Sadjad, S. (1993). Dari Benih Kepada Benih. Grasindo, Jakarta, 143.

Saeedipour, S. (2013). Effect of phytohormone seed priming on germination and seedling growth of cowpea (Vigna sinensis L.) under a different duration of treatment. International Journal of BioScience, 3(12), 187-192.

Shabbir, I., Ayub, M., Tahir, M., Bilal, M., Tanveer, A., Hussain, M., \& Afzal, M. (2014). Impact of priming techniques on emergence and seedling growth of sesame (Sesamum indicum L.) Genotypes. Scientia, 1(3), 92-96.

Singh, A., Dahiru, R., Musa, M., \& Sani Haliru, B. (2014). Effect of Osmopriming duration on germination, emergence, and early growth of Cowpea (Vigna unguiculata (L.) Walp.) in the Sudan Savanna of Nigeria. International Journal of Agronomy, 2014.

Sittadewi, E. H. (2007). Pengolahan Bahan Organik Eceng Gondok Menjadi Media Tumbuh Untuk Mendukung Pertanian Organik. Teknologi Lingkungan, 8(3), 229-234.

Sivritepe, N. (2008). Organic priming with seaweed extract (Ascophyllum nodosum) affects viability of pepper seeds. Asian Journal of Chemistry, 20(7), 5689.

Sutopo, L. (2004). Teknologi Benih, Revisi. ed. PT Raja Grafindo Persada, Jakarta.

Toharudin, M., \& Sutomo, H. (2013). Pengaruh Pemberian Pupuk Nitrogen dan Zat Pengatur Tumbuh Giberelin Terhadap Serapan N, Pertumbuhan dan Hasil Tanaman Padi (Oryza sativa L.) Kultivar Inpari 10. Agroswagati Jurnal Agronomi, 1(2).

Ummah, K., \& Rahayu, Y. S. (2019). The Effect of Gibberellin Extracted from Eichhornia crassipes Root on the Viability and Duration of Hard Seed Germination. Journal of Physics: Conference Series, 1417(1), 12037.

Vidya, S., \& Girish, L. (2014). Water hyacinth as green manure for organic farming. International Journal of Research in Applied, Natural and Social Sciences, 2(6), 65-72.

Wahdah, R., \& Susanti, H. (2019). Respon Viabilitas Benih Kacang Nagara (Vigna unguiculata ssp. Cylindrica) terhadap Invigorasi Benih Menggunakan Peg (Poli Etilen Glikol) Prosiding Seminar Nasional Lingkungan Lahan Basah, 4(1), 117125.

http://snllb.ulm.ac.id/prosiding/index. $\mathrm{php} / \mathrm{snllb}-$ lit/article/view/170

Wahdah, R., \& Susanti, H. (2020). Respon Viabilitas Benih Kacang Nagara (Vigna unguiculata ssp. Cylindrica) terhadap Osmoconditioning dengan Peg (Polietilen Glikol) pada Beberapa Lama Perendaman. Prosiding Seminar Nasional Lingkungan Lahan Basah, 5(3), 143-151. 
Widodo, A., Suharti, P., \& Listiana, L. (2016). Pengaruh Filtrat Eceng Gondok (Eichornia Crassipes) pada Media AB Mix terhadap Pertumbuhan

Tanaman Kangkung (Ipomoea reptans, Poir) dengan Hidroponik Wick System dan Pemanfaatannya Sebagai Media Informasi Bagi Pendidikan Ke Masyarakat. Universitas Muhammadiyah Surabaya.

\section{UCAPAN TERIMAKASIH}

Ucapan terimakasih disampaikan kepada LPPM Universitas Lambung Mangkurat atas dana penelitian yang diberikan dengan Kontrak Penelitian Nomor : 212.271/UN8.2/PL/2020. 